\title{
Old Wine in New Wineskins? A Trial of Restorative Justice in a Korean Criminal Court
}

\author{
Won Kyung CHANG* \\ Ewha Womans University, Seoul
}

\begin{abstract}
The concept of restorative justice emerged from efforts to find an alternative to the traditional punitive, retributive reaction to crime. The belief that face-to-face meetings are able to address the diverse needs of all involved parties has eventuated in the proposal of an informal process to discuss the aftermath of crime. One local district court in Korea was very keen to test this process and conducted a project to examine the applicability of restorative justice in Korean criminal trials. Investigating the processes and outcomes of this project, this study identifies challenges in officially adopting such a programme in Korea. In particular, this study raises questions regarding what form of justice Korean citizens truly desire.
\end{abstract}

Keywords: restorative justice, victim-offender mediation, criminal mediation, victims of crime justice preferences, public expectations of justice, public opinions about justice

\section{INTRODUCTION}

What if the execution of justice always focused on reconciliation, and was never tainted by elements of revenge or destructive punishment? What if we all understood that the true wrong in criminal behaviour was the harm it caused to person-to-person relationships rather than the violation of a law? As human beings, have we developed the capacity to forgive as we ask others to forgive us? Are we willing to contribute to the emotional and physical healing of a person harmed by crime? Are we able to lead a person who has committed crime to acknowledge their wrongful behaviour and inspire them to transform their ways in the future?

There is a perception that the concepts above were once adhered to by tribes sitting around a communal fire or drum in ancient times, or by people who lived in societies where all interactions revolved around families or clans. These societies were small, compact, and self-sufficient. Members spent time together face to face, shared common moral values, and held a concept of community spirited by co-operation. There were no sequestered judicial branches dealing with criminals; rather, a community that shared common values meted out justice directly.

* Assistant Professor, Scranton Honors Program, Ewha Womans University. Correspondence to Won Kyung Chang, 52 Ewhayeodae-gil, Seodaemun-gu, Seoul, 03760, South Korea. E-mail address: wonchang@ewha.ac.kr. This work was supported by the Ministry of Education of the Republic of Korea and the National Research Foundation of Korea (NRF-2014S1A5A8018621). 
The theory of restorative justice says that today's modern society could — and shouldrekindle some of these humanistic practices. ${ }^{1}$ Society's trend toward excessive individualism and the constant erosion of interpersonal bonds have contributed to soaring crime rates. ${ }^{2}$ In order to counter these trends, restorative justice proponents believe that society must fundamentally change its reaction to crime. Justice has become an abstract commodity manufactured by the state as a practical answer to crime. However, this state-oriented criminal justice system that perceives crime as a violation of an abstract criminal law, rather than a tangible action against the real interests of individuals and communities, has failed to address the needs of victims, communities, and even offenders. ${ }^{3}$ Thus, restorative justice theorists recall practices of man's earliest recorded reaction to crime and seek to create an alternative, dynamic, and ongoing process. ${ }^{4}$ This process should be negotiated and agreed upon by the parties most directly involved in particular offences_-victims, offenders, supporters of both, and other valid stakeholders. ${ }^{5}$

The idea of restorative justice, therefore, seeks to heal relationships harmed by crime, by taking into account the material and emotional damage crime exacts on the individuals involved. ${ }^{6}$ The core values in restorative justice are empowerment, participation, selfdetermination, reconciliation, healing, and reintegration into society. ${ }^{7}$ Indicating these values as guiding principles, restorative justice advocates argue that governments should cede monopoly over criminal cases to those directly impacted, but who otherwise may not be included in conventional proceedings. ${ }^{8}$ They hope that restorative justice principles will gradually supplant the current retributive, punitive response to crime. ${ }^{9}$ One of the bestknown restorative justice scholars, Daniel W. Van Ness, likens it to "new wine from old vines"-in other words, a new practice of an ancient concept of justice. ${ }^{10}$ In his work, he both pre-empted and addressed questions that could be raised about pouring the new wine of restorative justice into the old wineskins of the state-oriented criminal justice system.

An attempt to pour the new wine of restorative justice into the old Korean wineskins of adult criminal trials ${ }^{11}$ was conducted in the Bucheon Branch Court of Incheon District Court in 2013. The goal of this pilot project was to examine the feasibility of implementing restorative justice principles into criminal trial procedure. This study surveys the processes and outcomes of cases in the pilot project, taking into account the dialogue that took place within the various restorative justice practices, and identifies challenges to officially adopting such a programme. In particular, the focus is on formulating the central question that determines the success or failure of its practice in Korea.

1. Braithwaite (2002), pp. 3-16; Umbreit (2001), pp. xxvii-xxxii.

2. Dzur \& Olson (2004), pp. 91-2.

3. Braithwaite \& Strang (2001), pp. 1-2; Dzur \& Olson, supra note 2, pp. 91-2; Shearing (2001), pp. 15-20; Sherman (2001), p. 35-7; Strang (2001), p. 69; Wachtel \& McCold (2001), pp. 114-15.

4. Bazemore \& Umbreit (1995), pp. 301-2; Braithwaite, supra note 1, pp. 3-10; Kurki (2000), pp. 264-5.

5. Johnstone (2004), p. 5; Johnstone \& Van Ness (2007), p. 5; Marshall (2003), p. 28.

6. Braithwaite \& Strang, supra note 3, pp. 1-2; Kurki, supra note 4, pp. 265-6.

7. Braithwaite, supra note 1, pp. 14-15.

8. Bayley (2001), pp. 218-19.

9. Bazemore \& Schiff (2004), pp. 49-50; Clear (2004), pp. 71-2; Harris (2004), pp. 118-20; Karp (2004), pp. 62-6; Umbreit et al. (2004), pp. 87-8.

10. Van Ness (1993), p. 276.

11. In the Korean justice system, trial and sentencing together form one phase of the judicial process. 


\section{PREVIOUS ATTEMPTS AT RESTORATIVE JUSTICE IN KOREA}

The idea of restorative justice was first introduced into the fields of criminal law and justice policy studies in Korea in the early 2000s. It was initially discussed largely in the context of "victim protection."12 As the inquisitorial system gradually transitioned to a trial-centred adversarial system with the 1954 enactment of the Criminal Procedure Act of Korea and its subsequent amendments, several steps were institutionalized to ensure the rights of suspects and defendants under criminal justice processes. Until the 1990s, however, the protection of victims' rights had hardly come into the purview of criminal justice policy. As the concept of restorative justice was first introduced to Korea, at a time when the necessity of victim protection was just beginning to be discussed in academia, restorative justice was mainly recognized in terms of victims' security and compensation for damages. ${ }^{13}$

Along with such theoretical discussions, since the mid-2000s, criminal justice policymakers have extensively redirected existing diversion programmes by adding some elements of restorative justice- such as apology or compensation to victims and the participation of community members. At the same time, several institutionalization schemes were presented to introduce restorative justice programmes into criminal and/or juvenile justice procedures. For instance, various pilot programmes labelled "restorative justice" were launched by criminal and juvenile justice agencies-such as the Seoul Metropolitan Police Agency, ${ }_{14}$ Changwon District Public Prosecutor's Office, ${ }^{15}$ the Supreme Prosecutor's Office, ${ }^{16}$ the Seoul Family Court, ${ }^{17}$ the Juvenile Protection Education Institute, ${ }^{18}$ the Seoul Probation Office, ${ }^{19}$ and the Seoul District Correctional Facility. ${ }^{20}$

Most of these programmes, however, contained only minimal elements of addressing the harm caused by crime or allowing participation of victims and/or community members. ${ }^{21}$ Only three reflected the essential elements of restorative justice-namely an informal process of face-to-face discussion among parties most directly involved in a particular offence $^{22}$ : (1) the family group conference applied to juvenile cases during the investigation phase, (2) the compromise recommendation introduced in juvenile courts at trial, and (3) the criminal mediation conducted in criminal cases before a prosecutor's decision to indict.

12. Lee, Ho-Joong (2009), p. 3.

13. Chung, June Young (2013), p. 546.

14. Kim, Eun-Kyung (2008), pp. 100-28; Kim, Eun-Kyeong (2009), pp. 57-73; Kim, Hang-Gon (2009), pp. 35-43.

15. Park, Sang-Sik (2007), p. 123.

16. Kim, Hyun (2009), pp. 55-8.

17. Kim, Eun-Kyeong, supra note 14, pp. 57-73; Lee, Young Hoon (2009), pp. 77-8.

18. Lee, Young-Ho (2009), pp. 95-103.

19. Lee, Sung Chil (2009), pp. 119-27.

20. Park, Jung-Sung \& Hyo-Jin Kim (2012), pp. 102-3; Shin, Yong-Hae (2009), pp. 142-7.

21. Several district public prosecutor's offices throughout the country held a "confinement review committee" or a "conference meeting for offense examination" in order to reflect opinions of victims and local residents before prosecutors made decisions on confinement or prosecution. Kim, Hyun, supra note 16, pp. 58-63. In addition, a small number of programmes operated in correctional facilities-represented by "sending letters of apology to victims," "reconciliation through voluntary donations of prisoners," and community service organizations composed of convicted prisoners - and probation offices' new training courses on sexual violence or domestic violence assailants to increase their understanding of victims of crime were labelled "restorative justice." Gang, Ho-Seong \& Seung-Weon Lee (2011), pp. 281-8; Kim, Yongshik (2013), pp. 281-9; Sohn, Yoi Chull (2011), pp. 99-102.

22. Johnstone \& Van Ness, supra note 5, p. 7. 
A trial run of Seoul Metropolitan Police Agency's family group conference was intended to help juvenile offenders, victims, and their family members in minor cases, such as school violence, to reconcile with each other. This pilot programme was implemented at several police stations in Seoul at two different periods in 2007. During the first pilot period, no case was referred to this programme due to an insufficient understanding of restorative justice by not only offenders and victims, but also police officers in charge. Thus, professional conferencing facilitators from private, nonprofit organizations explained the concept of restorative justice to the victims and offenders of given cases during the second pilot period. Parties in six of ten cases referred to this family group conference came to a settlement. ${ }^{23}$ After this preliminary attempt, this programme was discontinued because police lacked authority to enforce conditions attached to release, rendering the settlements made between victims and offenders legally meaningless. $^{24}$

A programme recommending compromise between offenders and victims in juvenile protection trials was inserted in the amendment of the Juvenile Act in December 2007 and came into force the following June. ${ }^{25}$ Consequently, the juvenile department at Seoul Family Court institutionalized the following operating procedures, pursuant to restorative justice notions: determine concrete criteria for cases in which recommendations for compromise are to be made, evaluate victims' willingness to participate, and designate three committee members to facilitate dialogue between offenders and victims. ${ }^{26}$ However, criticisms have been raised that this programme does not reflect the true idea of restorative justice, because offenders are in fact forced to participate, and because only reconciliations between offenders and victims made in court are acknowledged (reconciliations made voluntarily before the commencement of the trial are not considered in the decision of protective disposition). ${ }^{27}$

As a process of mediating between offenders and victims, criminal mediation has been officially implemented in property crime cases and minor violence cases in the preindictment phase since August 2007. ${ }^{28}$ With the amendment of the Crime Victim Protection Act in May 2010, provisions were established, ${ }^{29}$ providing legal grounds for a prosecutor to refer criminal cases to the mediation committees set up at each public prosecutor's office. ${ }^{30}$ Criminal mediation has been evaluated as contributing to the actual recovery of criminal harm, because a substantial number of victims every year receive monetary compensation from settlements with offenders through this process. ${ }^{31}$ However, the current criminal

23. Kim, Eun-Kyung, supra note 14, pp. 100-28.

24. Kim, Hang-gon, supra note 14, pp. 35-46.

25. Juvenile Act, Article 25-3. Korea Legislation Research Institute, Statutes of the Republic of Korea (2017b).

26. Shin, Han Mi (2011), pp. 78-85; Sun, Ui Jong (2010), pp. 37-43.

27. Chun, Jung Hwan (2015), pp. 21-9; Jung, Hee-Cheol (2011), pp. 107-9; Kang, Jee-Myoung (2012), pp. 120-2; Lee, Jin-Kuk (2009), pp. 363-8.

28. Jung, Ji-Young (2013), pp. 70-4; Song, Gil Yong (2007), pp. 177-80.

29. Crime Victim Protection Act, Articles 41-46, Korea Legislation Research Institute, Statutes of the Republic of Korea (2017a)

30. Park, Kwang-Hyun (2014), p. 267.

31. Since its implementation in 2007, the number of cases referred increased every year to the extent that, in 2014, 54,691 cases (3\% of all criminal cases) were referred, and settlements were made in 25,523 cases (56.1\% of referred cases). Lee, Bo-Young (2015), p. 72. Recently, other than the settlement rate, participants' demographic characteristics and degree of satisfaction both the process and outcome, etc., were studied to evaluate the effectiveness of criminal mediation. Joo, Jae-Ung (2014), pp. 238-57; Lee, Dong Weon (2011), pp. 119-31; Lee, Dong Weon \& Hyun Seok Yoon (2016), pp. 182-200. 
mediation system is mainly utilized to reach agreement on the amount of compensation for damages in cases where civil disputes - in particular, those that occurred due to monetary transactions between individuals - became criminal cases through one party's pressing charges. This too has attracted criticism that the programme is restorative justice in name only. ${ }^{32}$

In spite of active discussions to adopt restorative justice into the Korean juvenile and criminal justice procedure since the early 2000s, only two programmes have been institutionalized-(1) a judge's recommendations for reconciliation at trial in juvenile protection cases and (2) a prosecutor's referral to criminal mediation in the pre-indictment stage in adult criminal cases. Furthermore, the restrictions on the autonomy of parties involved and the exclusive focus on parties' discourse regarding the amount of compensation for damages incurred have fostered scepticism of whether the aforementioned two programmes even faithfully reflect the ideas of restorative justice.

\section{PILOT PROJECT IN A KOREAN CRIMINAL COURT}

\subsection{Background}

The pilot project implemented at the Bucheon Branch Court of Incheon District Court was an attempt to overcome such limitations of existing restorative justice programmes and to conceive how to harmonize the present retributive and adversarial process into restorative justice principles. Several judges, including the chief judge of Bucheon Branch Court, shared recognition that the current criminal justice procedure is optimized for investigating evidence through legitimate steps and punishing the accused based on the principle of responsibility, but fails to respect victims and offenders in the process and to help the recovery of trust between parties. These judges presented the future direction of the criminal justice system as moving from judgment towards healing, and suggested that restorative justice could help to construct a better society by addressing individual needs and respecting individuals on their own terms.

In order to test the suitability of restorative justice practice in Korean criminal trials and to unearth any practical obstacles against such implementation, the Bucheon Branch Court carried out this pilot project from August to December 2013. The principles of restorative justice were applied to serious adult violence and/or property cases during criminal trials for the first time in Korea.

Bucheon Branch Court held the initiative in leading this pilot project, similar to other restorative justice programmes tried in Korea, while endeavouring to form a social consensus from the local community and to induce co-operation from related public and private organizations. As one step toward broadening the local community's understanding of restorative justice, the Bucheon Branch Court held a joint forum entitled "Restorative Justice in the Bucheon Community: Making this a Safe and Peaceful City" in April 2013. ${ }^{33}$ The Bucheon Branch Court further drove the preparation of this pilot project under the co-operation of the Prosecutor's Office within the jurisdiction and court-appointed counsels, ${ }^{34}$ especially for identifying appropriate cases and providing legal support for defendants who participated.

32. Kim, Yong-Uk (2008), pp. 223-4; Lee, Jin-Kuk (2008), p. 20; Shin, Yang-Kyun (2009), p. 464.

33. Bucheon Branch Court of Incheon District Court (2014), pp. 15-16.

34. In 2006, Korea adopted a system for courts to appoint a lawyer to be exclusively in charge of a case as stateappointed defence counsel. Regulation on Criminal Procedure, Article 15-2. Korea Legislation Research Institute, Statutes of the Republic of Korea (2017c). 
In addition, six private institutions agreed to participate, which were the most active proponents and practitioners of restorative justice methodologies and conflict management techniques in Korean civil society: the Korea Institute of Conflict Management and Mediation, the Korean Centre for Nonviolent Communication, the Conflict Resolution Centre at Women Making Peace, the Korea Peacebuilding Institute, Nonviolent Peaceforce Corea, and the Restorative Justice Centre at Ewha Law School. These institutions consented to conduct the core part of this pilot project-arranging restorative encounters between victims and offenders and facilitating their communication-without receiving any financial compensation in exchange.

The initiation and progression of this pilot project are very exceptional in Korea, where the national government's National Court Administration, headed by a minister who concurrently serves as a justice, still controls most judicial policies. However, this project was launched by a local branch of district court, namely Bucheon Branch Court, and proceeded through co-operation with several public and private organizations in accordance with the core values of restorative justice-voluntary participation of all involved parties and self-determination based on empowerment. This type of co-operation has frequently appeared in the many inchoate restorative justice programmes in Western countries, where the practice of restorative justice was first initiated by private, nonprofit organizations rather than governmental agencies. ${ }^{35}$ Similarly to many Western examples of beginning restorative justice in a local community, the Bucheon Branch Court, while leading this pilot project, tried to share its motivation to implement restorative justice in a local community with other grassroots organizations.

\subsection{The Project}

One criminal court judge in Bucheon Branch Court was assigned to implement this pilot project, and she resolved many legal and practical issues brought up in the process of bringing a restorative justice programme into the trial, deciding upon detailed procedures. The restorative justice professionals from the six private institutions actually led the restorative justice practices in the referred cases. The models of restorative justice employed differed depending on the institutions (shown in Table 1), but all agreed that the basis should be found in an informal process of discussing the aftermath of a crime by empowering parties most directly involved in a particular offence. Thus, the victim-offender mediation model used most was one in which trained facilitators led meetings in a safe place.

The restorative justice sessions were totally separated from process of the trial itself and proceeded independently, led by restorative justice professionals after receiving criminal cases referred to them. The sessions were conducted in rooms for mediation located inside or outside the court building, wherever the parties agreed. The judge in charge of this project received the result of restorative justice submitted by the defendant as material to use in assessing the case, as in other cases, and then considered it when deciding sentencing. However, she was engaged in the referral process by determining cases suitable for restorative justice practices and questioning both defendant and victim on their willingness to go through with it. In order to ask the victim's intent to participate, the judge summoned the victim as an ex efficio sentencing witness to the courtroom. Upon first inspection, this would

35. Umbreit, supra note 1, pp. 112-13. 


\begin{tabular}{|c|c|c|c|c|c|c|}
\hline Case & Defendant & Victim* & Crime & Institutions & $\begin{array}{l}\text { Restorative Justice } \\
\text { Model }\end{array}$ & $\begin{array}{l}\text { Final agreement } \\
\text { reached? }\end{array}$ \\
\hline$\# 1$ & Male, 58 & Female & Inflicting bodily injury with a deadly weapon & $\begin{array}{l}\text { Korea Institute of Conflict } \\
\text { Management and Mediation }\end{array}$ & Mediation model & Yes \\
\hline \#2 & Male, 19 & Female, 18 & $\begin{array}{l}\text { Illegal confinement, Inflicting bodily injury, } \\
\text { Destruction of property }\end{array}$ & & $\begin{array}{l}\text { One-party consultation } \\
\text { model }\end{array}$ & No \\
\hline \#3 & Male, 45 & $\begin{array}{l}\text { Deceased } \\
\text { (Female, 22) }\end{array}$ & $\begin{array}{l}\text { Violation of the "Act on Special Cases } \\
\text { concerning the Settlement of Traffic } \\
\text { Accidents" }\end{array}$ & $\begin{array}{l}\text { The Korean Centre for } \\
\text { Nonviolent Communication }\end{array}$ & $\begin{array}{l}\text { Nonviolent } \\
\text { communication conflict } \\
\text { solving model }\end{array}$ & Yes \\
\hline \#4 & Male, 33 & Male, 23 & Inflicting bodily injury & & $\begin{array}{l}\text { Nonviolent } \\
\text { communication conflict } \\
\text { solving model }\end{array}$ & $\begin{array}{l}\text { Yes, but later } \\
\text { breached by } \\
\text { defendant }\end{array}$ \\
\hline \#5 & $\begin{array}{l}\text { Male, } 27 \\
\text { Male, } 28\end{array}$ & $\begin{array}{l}\text { Male } \\
\text { Female }\end{array}$ & $\begin{array}{l}\text { Inflicting bodily injury jointly committed by } \\
\text { two or more persons }\end{array}$ & $\begin{array}{l}\text { Conflict Resolution Centre at } \\
\text { Women Making Peace }\end{array}$ & Mediation model & No \\
\hline \#6 & Male, 54 & Female & Intimidation with a deadly weapon, Assault & & Mediation model & $\begin{array}{l}\text { Yes, parties agreed } \\
\text { to a divorce too }\end{array}$ \\
\hline \#7 & Male, 46 & Male & Destruction of property, Inflicting bodily injury & Korea Peacebuilding Institute & - & Yes \\
\hline \multirow[t]{2}{*}{ \#8 } & Male, 45 & $\begin{array}{l}\text { Male, } 47 \\
\quad \text { (co-defendant) }\end{array}$ & $\begin{array}{l}\text { Interference with business, Inflicting bodily } \\
\text { injury, Intimidation }\end{array}$ & & Mediation model & Yes \\
\hline & Male, 47 & $\begin{array}{l}\text { Male, } 45 \\
\text { (co-defendant) }\end{array}$ & Inflicting bodily injury & & & \\
\hline \multirow[t]{2}{*}{$\# 9$} & Female, 74 & Female & Insult, Assault & Nonviolent Peaceforce Corea & Circle model & No \\
\hline & Male, 68 & $\begin{array}{l}\text { Female, } 74 \\
\text { (co-defendant) }\end{array}$ & Inflicting bodily injury & & & \\
\hline \#10 & Male, 42 & Male & Inflicting bodily injury with a deadly weapon & $\begin{array}{l}\text { Restorative Justice Center at } \\
\text { Ewha Law School }\end{array}$ & Mediation model & No \\
\hline
\end{tabular}

*Age of victims not available in all cases. 
seem to interfere with the victim's voluntary choice, but the judge conducted this process very carefully in order to guarantee the maximum level of victim autonomy.

Twelve individual cases combined into ten (because of overlapping parties or matters) were dealt with in this pilot project. Physical injury was involved in all cases, and Case \#3 involved the victim's death due to a car accident. In the general process of adopting restorative justice in the conventional criminal justice system (both in Western countries, particularly the US, and in Korea), it is customary that principles are first applied to cases involving property crime and/or minor violence, and then extended to other, more serious types of crime. ${ }^{36}$ However, in this pilot project, cases where severe violence was involved were selected if they fitted the following criteria: (1) there was no dispute on the facts of the case, (2) monetary compensation for damages was both necessary and possible, and (3) defendant and victim required a mediator to facilitate dialogue. ${ }^{37}$ The details of the cases are summarized in Table 1.

Of the ten cases, six reached agreement while the rest did not. However, whether an agreement was reached should not be considered the only criterion for evaluating the effectiveness of restorative justice practices. In Case \#7, the parties ultimately reached an agreement, but this was only possible because of the defence counsel's efforts, in spite of the victim's refusal to confront the defendant. On the other hand, the defendants in Case \#9 managed to work through a considerable level of rage and feelings of helplessness caused by the crimes, and laid the groundwork for further conversations, even though they could not sign the final agreement. ${ }^{38}$

\section{ONE SUCCESS AND MANY CHALLENGES}

\subsection{Challenges in the Referral Phase}

One of the first tasks when referring cases to restorative justice practices is to clarify the key concepts of restorative justice to the potential participants - those who have never expected to experience reconciliation and forgiveness after a crime was committed, but were instead used to retribution and punishment. The judge in charge of this pilot project mentioned that the most difficult part of implementing it was informing the parties of the idea of restorative justice, explaining the value of going through the restorative justice practice, and ascertaining their willingness to participate. In a report published after this pilot project, she described this difficulty:

[A]s the judge who conducted this pilot project, it seemed to me that proposing the philosophy or perspective of restorative justice to the parties who were familiar with the traditional punitive judicial system and implementing restorative justice procedures in the trial were like a sort of "shift," as if I were transferring the parties from one dimension to another .... Thus, I named this stage the "lead-in process"- the work of persuading the defendant and victim to become

36. Ibid., pp. 85-109, 113-14, 255.

37. Bucheon Branch Court of Incheon District Court, supra note 33, pp. 22-3.

38. Information regarding each case came from my fieldwork of this pilot project. I conducted research through interviews with the judge, the attorneys for the defendants and victims, and restorative justice facilitators, since I was restricted from directly communicating with the victims and offenders in each case. In addition, I utilized other publicly available materials such as written judgments and a published report of this pilot project. In my detailed description of each case, I use quotations when directly quoting participants' statements from the published report. However, all descriptions and analyses were based on my field notes taken at the Bucheon Branch Court of Incheon District Court. 
interested in the concept of restorative justice and come to the table rather than being constrained by the conventional punitive paradigm. I conducted this process delicately, taking considerable time and effort, while receiving counselling from and monitoring by restorative justice professionals. ${ }^{39}$

Not every case she had in mind successfully passed this lead-in process. She stated that a considerable number of cases that she gauged as appropriate for this pilot project were ultimately not referred to the restorative justice institutions. Furthermore, even among those cases where the judge believed that the lead-in process was successfully completed, some victims refused to meet the defendants, preferring an eye for an eye.

[Case \#2: Punishment as payback] Case \#2 was referred to a restorative justice process, despite the victim's initial rejection of the judge's proposal. The Korea Institute of Conflict Management and Mediation decided to employ a one-party consultation model for this case for the purpose of empowering the defendant, whose intellectual capacity was considerably lower than that of his peers, and also for building his capacity to reconcile.

The defendant, $A$, and the victim, $B$, had been in a relationship. When $B$ wanted to break up with $A$, the latter became furious and confined $B$ in his car for about 20 minutes, slapped her face, and hit her in the abdomen, leaving $B$ with injuries that required about two weeks to heal completely. He also threw her phone, damaging it. Since $A$ was unable to comprehend the seriousness of his behaviour and to anticipate what lay ahead of him, restorative justice professionals assisted him to realize the cause of the conflict and to practise normal communication and apologize to $B$. After three rounds of face-to-face coaching by the restorative justice professionals, $A$ tried to contact $B$, his ex-girlfriend, through several communication channels to offer her an apology. However, $B$ did not respond on any occasion, instead conveying the message that she had no intention to accept the apology, because her new boyfriend had been punished by law for assaulting $A$ in a separate incident. To the victim, criminal punishment of the defendant was a way to exact revenge, and she showed not the slightest change in her attitude toward the defendant, her ex-boyfriend, throughout the course of his reaching out for restorative dialogue.

[Case \#7: Noisy neighbours] The victim in Case \#7 answered "yes" to the judge when participating in a restorative justice process was suggested, but he wanted to solve the situation only through the courts. The defendant, $A$, who lived with his wife and middleschool-aged daughter, often had arguments with the victim, $B$, who lived upstairs with his wife and two little children, regarding the noise that $B$ 's family made. On the day in question, a drunken $A$ went to $B$ 's apartment at around 2 a.m., complaining about the noise, and threw a stroller that stood in the entrance, damaging the front door. He went back again in the morning to destroy the door-lock because $B$ had not opened the door for him when he had rung the bell. When the police showed up after receiving an emergency call, defendant $A$ got angry and kicked $B$ 's leg. $B$ was planning to move because of this incident, and refused to talk to the defendant directly.

Since the victim could not be contacted by the Korea Peacebuilding Institute- the restorative justice institution handling this case-a preliminary session for restorative justice was scheduled with the defendant only. Even before holding this preliminary session, however, a private attorney for $A$ visited $B$, reaching an agreement for the amount of

39. Bucheon Branch Court of Incheon District Court, supra note 33, pp. 24-5. 
compensation, and submitted it to the court. Thus, the parties reached a settlement legally, but neither direct nor indirect communication between the parties took place, except concerning the amount of compensation.

[Case \#10: Colleague's cue] No meaningful restorative encounter between victim and defendant happened in Case \#10, either, because the victim was not of a mind to listen to the defendant's side of the story. The defendant $A$, a managing director at a nightclub, and the victim, $B$, a waiter at the same venue, had worked together for about four years. Several days after $A$ had fired $B$ for absence without leave, $B$ showed up drunk and swore at him. $A$ became so enraged that he tripped $B$, kicked him in the head, and hit his head with a billiard cue, which left $B$ with injuries including serious brain damage.

The victim's wife, who appeared in court as an ex officio sentencing witness, consented to the referral to a restorative justice process, but neither she nor her husband appeared at the preliminary session, without giving prior notice. The Restorative Justice Centre at Ewha Law School contacted them through several phone calls and text messages, and the victim's civil suit attorney and the victim's mother-in-law attended the victim-offender joint session for mediation. The victim's mother-in-law repeatedly stated that they had no intention of forgiving the defendant or signing any form of settlement. Throughout the judicial process, the defendant kept arguing that the victim was exaggerating his injuries and submitted photos and depositions as evidence that the victim was in fact uninjured, which infuriated the victim and his wife. As a result, they did not feel the defendant was sincere in his apology and could only think about the hurt and injustice caused by this incident.

All victims in the above-mentioned three cases did not have any willingness to open their mind to the other party and start honest communication, even though those in Cases \#7 [Noisy neighbours] and \#10 [Colleague's cue] consented to the referral proposed by the judge. This consent was only out of fear that they would suffer some disadvantage if they refused, rather than consent based on a sincere approval of the idea of restorative justice and aiming to seriously explore the possible solutions. Not only were all victims ignorant of restorative justice; they also lacked any experience of reconciling with others who had wronged them, and feeling some level of satisfaction through compromise and reconciliation. Thus, the victim in Case \#7 [Noisy neighbours] hoped to resolve the dispute by avoiding the situation through moving out and seeking compensation. The victim in Case \#2 [Punishment as payback] even deemed judicial process and punishment as a sort of revenge by relating it in her mind to another separate but related incident. Analysis of these cases suggests that restorative justice would get off on the right foot only when the direct parties to the incident in question can open their minds and understand the pleasure that comes from deep conversation with the other party.

\subsection{Challenges in the Negotiation Phase}

Similar problems observed in the referral phase-difficulties in "shifting" the criminal justice tendency of the parties, especially victims, from retribution to restoration-appeared in the negotiation phase as well. The victims who attended the face-to-face negotiation phase of the restorative justice process got through the referral phase and were somewhat ready to conduct a serious conversation with the defendant about their side of the story. However, it became apparent that the victims who chose this pilot project did so with various motives. 
Based on the attitudes shown in the negotiation phase, these were cases where the victims strategically chose restorative justice in order to raise the amount of compensation they could receive, and in some cases in order to demonstrate their victimhood and to turn the case to their advantage.

[Case \#1: Fighting over junk] The victim in Case \#1 showed a strong desire to manipulate and control the whole process for her advantage. The defendant, $A$, made a living by collecting junk and the victim, $B$, was a neighbour living across from $A$ 's house, and used to complain to $A$ about stacking junk around $B$ 's house. On the day in question, $A$ saw $B$ passing by and stabbed her in the ribcage with a knife, seriously injuring her. The parties were neighbours, but they were so aggrieved at each other that it was impossible to face or talk to each other in a courtroom. Furthermore, the victim suspected the true reason for referring this case to the restorative justice process was in order to benefit the defendant.

Individual preliminary sessions for both the victim and the defendant were scheduled on the same day within several hours of each other, and the date for the joint session was to be discussed after completing the two preliminary sessions. However, at the end of the victim's preliminary session, she strongly insisted on conducting the joint mediation session on the same day, arguing that she could not come on another day, and did not want to go through a similar meeting again. Since it was hard to suggest any other option, the joint mediation session actually took place right after the defendant's preliminary session, and the process itself began to be controlled by the victim, who had been waiting to confront the defendant. In addition, in spite of facilitators' effort to maintain the balance of power, the victim demanded a focus only on her argument by emphasizing how traumatized she was because of the sudden attack by the defendant on the street.

Defendant and victim finally agreed that the defendant would move out and pay for the victim's medical expenses. The defence lawyer assigned by the court in this case, having observed the whole discussion between the defendant and victim, commented that "[s]etting the monetary compensation aside, the agreement on the defendant's moving out cannot be considered a reasonable agreement, even allowing for the victim's state of mind after being attacked and her concern for further injury." her advantageous position both in controlling the process and in forcing an agreement.

[Case \#6: Death before divorce] The progress and result of restorative justice practice in Case \#6 also proceeded in favour of the victim compared to other similar cases. The defendant, $A$, paid a sudden visit to the workplace of $B$, a woman he had married ten years ago but had abandoned due to marital conflict. $A$ lost his temper when $B$ 's colleague $C$ treated him rudely, and $A$ assaulted $C$ by hitting her in the face with his hand and threatening to kill both $B$ and $C$ with a knife he had with him. The entire case was referred to a restorative justice practice, but the main joint session was held only between $A$ and his estranged wife $B$. The defendant wanted to remain married and to settle this case of criminal assault and intimidation, but the wife insisted on divorcing, pointing out $A$ 's constant hard-drinking lifestyle and sexual harassment of both herself and her daughter.

Over the five-hour joint mediation session, the defendant and victim, namely the husband and estranged wife, engaged in deep conversation regarding a series of incidents that had happened between them, as well as the assault and intimidation in this case. The defendant

40. Ibid., p. 221. 
finally came to understand the fear and terror felt by his wife during their marriage and agreed to a divorce if that was the only solution palatable to her. Consequently, $A$ and $B$ agreed to divorce, and $A$ agreed to transfer his only real estate to $B$ as partial payment of consolation money, as division of property, and as payment of settlement money for the criminal case. Both $B$ and $C$, victims of the assault and intimidation at their workplace, announced their intention not to press charges against the defendant.

Parties in this case were eventually able to solve relevant legal issues over criminal, civil, and family matters all at once through the restorative justice process. However, the terms of the agreement and the process of discussion itself could be evaluated as being somewhat harsh on the defendant. The court-assigned counsel who participated in the mediation pointed out that the conflict-solving process appeared to favour the female victim, saying " $[\mathrm{t}]$ here is a possibility that the male defendant, who is the offender in this abusive relationship, might have been psychologically intimidated during the session that took place in a professional counselling institution composed of women only."41

[Case \#5: Violence on the island] Case \#5 was a simple case of violence between strangers at a popular tourist destination, Jeju Island. The defendants, cousins $A$ and $A$,' got drunk one night and fell into a quarrel with the male victim, $B$, who was also drunk at the time because he had bumped into them in front of a motel. The defendants jointly assaulted $B$ and his wife $B$ ', leaving them both with serious injuries. The parties had met by chance on Jeju Island and, unlike parties in other cases, the victims only claimed "monetary compensation" without any alternative.

From the preliminary session to the joint mediation session, the victims' only concern was the total amount of damages and settlement money they would receive. They were enraged that the defendants appointed private attorneys, when they had previously stated that "they could not afford one," and stated a desire to increase the amount of settlement money, since they knew that the defendants could apparently afford it. Because of a considerable gap between the victims' demand and the amount of settlement money that the defendants could afford to pay, an agreement was not reached. In addition, even after the judge sentenced the defendants, the victims complained to the prosecutor's office and demanded an appeal for more compensation (this was impossible). In this case, the victims manifestly indicated their intention to participate in restorative justice process as a strategic means to raise the amount of compensation.

[Case \#9: Rob thy neighbour] Case \#9 involved an insult, assault, and injury among three residents (two are a couple) of the same village - the defendant $A$ insulted $B$ ' and assaulted $B$, and then co-defendant $B$ injured $A$. The defendant $A$ had known $B$ ', a woman in the same village, for 30 years and they had been close friends until they became estranged five years ago. At an unknown point in time, $A$ began spreading rumours that $B^{\prime}$ had stolen several articles from her house, which upset $B^{\prime}$ very much. On the day in question, $A$ publicly insulted $B$ ', who was coming out of her church after worship, calling her "a thief" in front of approximately 100 church members. The co-defendant $B$, the husband of $B$ ', tried to stop this and he injured $A$ in the course of dragging her away by her arm. $A$ then kicked co-defendant $B$ and assaulted him by slapping him in the face.

Nonviolence Peaceforce Corea, which took this case, applied the circle model of restorative justice, the only case of its kind in this pilot project. The facilitators had individual

41. Ibid., p. 225. 
conversations with $A$ and the couple $B-B$ ' in several preliminary sessions. In particular, since $A$ lacked both a social network and any means of financial support apart from collecting and selling waste paper, the facilitators attempted for over two months to build a support system for her, such as helping her get psychiatric assistance, counselling, and social welfare support. Finally, a social worker and a counsellor from the Senior Welfare Centre in that region participated in both the preliminary session with $A$ and the joint session among $A, B$, and $B$ '. Over the four hours of conversation, $A$ expressed how much she had been disappointed by $B^{\prime}$, and $B$ ' and $B$ were able to get some insight into why $A$ had harassed them. Through the process, they reached an agreement to (1) not visit each other's houses, (2) greet each other when they run into each other on the street, and (3) withdraw the three criminal charges. At the last minute, however, $A$ hesitated to withdraw the civil lawsuit in which she claimed compensation for articles $B$ ' had allegedly stolen from her house, and they failed to reach a final agreement.

After the adjournment of the joint session, $A$ visited a free legal aid centre for consultation and withdrew the agreement made in the restorative justice circle following the legal advice of the legal aid centre. Since she held a list of articles that had disappeared from her house, the legal aid centre advised her to seek monetary compensation through a civil lawsuit. In the end, all the psychotherapy, counselling, and social welfare support for $A$, conducted over several months, ended up being derailed by the advice from the legal aid centre, an institution that lacked contextual background about $A$. This legal advice ultimately moved the focus from creating a social welfare support system for $A$, who was economically and psychologically vulnerable, to legal issues such as who was right and whose evidence was stronger. In spite of the long and unusual efforts by Nonviolence Peaceforce Corea, all that mattered to $A$ was the allegation that $B$ ' took her property and the legal matters related to getting proper compensation.

The lack of sincere understanding of the concept of restorative justice itself among the disputing parties eventuated in frequent failure in the negotiation phase. The parties, especially the victims, showed their intentions to maximize their benefits by participating in the restorative justice process, rather than a desire for in-depth understanding of each other through more humane and honest conversations that were not possible in the traditional judicial system. For instance, the victims in Case \#5 [Violence on the island] chose restorative justice as a means to raise the amount of compensation, and the defendant in Case \#9 [Rob thy neighbour] chose legal recourse over the personal conversation and institutional support she received from the restorative justice process. In addition, since the victim in many cases knew that the defendant faced the risk of a jail sentence if he/she failed to participate in a restorative justice process, the victim took advantage of the situation in which the defendant had no choice but to accept his/her proposal. As a result, a power imbalance occurs between victim and offender, as seen in Cases \#1 [Fighting over junk] and \#6 [Death before divorce], in which the victim controlled the whole process or made extreme requests. These cases revealed that insincere adoption of restorative justice by parties who could not empathize with its true goals would bring about more problematic conclusions.

\subsection{One Successful Case}

This pilot project highlighted how much of a challenge it is to invite the parties most directly involved in a crime to redirect their predisposed concepts of crime and punishment and to 
inspire new reactions towards the other party. Nonetheless, one case hinted at the potential feasibility of implementing restorative justice in Korea.

[Case \#3: Car accident] Everyone in this case-the judge, facilitators from the Korean Centre for Nonviolent Communication, court-appointed counsel, and even the partiesexpressed satisfaction regarding the process and outcome of restorative justice. The defendant, $A$, worked from 5 p.m. to 5 a.m. and, on the day in question, when he was driving home at around 5:40 a.m., he did not see the victim, $B$, who was on her way to her part-time job, crossing the road in her in-line skates. Consequently, he ran her over and killed her. In the process of conventional criminal justice, the defendant and the family of the deceased victim became so upset at each other that the victim's family was pushing for the defendant to receive a severe punishment. The victim's father initially refused to participate in the restorative justice process, but changed his mind after receiving a phone call from the Korean Centre for Nonviolent Communication-the restorative justice institution that took on this case.

Before the preliminary session of the restorative justice process, each party revealed extremely hostile feelings and aggressive responses toward each other that could be plainly seen in the text messages back and forth between each other. The victim's father texted the defendant: "I will do the exact same thing to your daughters. I will never settle for less than 50 million won." The defendant replied:

[y]ou are trash to kick your daughter out of the house at 5 a.m. to make money .... You obviously lied when you said that you did not want to make a fortune out of her. You are such an evil person to blackmail me like this! You made a living by exploiting your 22-year-old daughter and now you want to take full advantage of the dead girl!

The victim's father expressed hurt feelings and an aggressive attitude toward the defendant at the start of the separate preliminary session with the victim's family. However, when the facilitators consoled him tenderly, he took a photo of his daughter from his wallet and burst into tears. His second daughter, younger sister of the victim, reacted to her father's tears: "It was the first time I'd seen him cry. At home, he never ate but drank only alcohol, never spoke but only heaved a sigh of despair staring into the sky." Over two hours of conversation, the victim's family felt somewhat comforted by the emotional support and unloaded their feelings, and the victim's father concluded that he would meet the defendant if he fell on his knees and begged for forgiveness.

The defendant's attitude changed more dramatically in the preliminary session, spurred on by the facilitator's opening question: "How have you been holding up?" The defendant explained his grievous situation after the incident-he had become a welfare recipient because he was not able to work due to a sleeping disorder, his family had fallen apart because his daughters had called the police when he became violent toward his wife after drinking, and his wife was demanding a divorce. The facilitators showed sympathy, and that gave him the psychological space to think about this situation from the perspective of the victim's family. Another preliminary session was conducted with the defendant and his wife, and he confessed how hurt he felt when he witnessed the destruction done to his family because of his mistake. He talked about his unhappy childhood due to his mother's death, the importance to him of raising two daughters and a family, and expressed his appreciation for his wife. His wife then accepted his apology and consoled him. 
In the joint mediation session, the confrontation between the victim's family and the defendant was uncomfortable at first, but both parties were able to sympathize with each other, unlike in previous encounters. The defendant sincerely apologized to the victim's family, and this was accepted by the victim's father. Once this had happened, a compensation settlement was reached smoothly and quickly. The defendant paid 10 million won immediately, and the parties agreed to conclude the entire civil-criminal legal dispute.

The court-appointed counsel for the defendant described the occasion when he met the victim's father again to get his signature on the written agreement:

When I met him at a café to get his signature on the written agreement, the victim's father talked a lot, often laughed, and seemed more relieved during one hour of our meeting, even though he wept a couple of times since he still missed his daughter. He told me that the text message received the day before from the defendant, whose number he had saved as "the bastard" in his phone, was so sincere that he almost cried. ${ }^{42}$

In addition, the judge stated that the defendant seemed very relieved and looked like a totally different person when he appeared in court for sentencing after the agreement. Furthermore, the defendant himself mentioned changes in his life in a conversation with one facilitator of his case two months after the agreement:

I sincerely thank the court for taking care of the human side. Now my life is better, I am getting healthier, I can sleep well at night, and most of all, my children have begun to talk again at home. My life has never been easy, but I was just out of my mind after the accident. All my family was having a hard time, with no one around us, and you were the only ones who offered us help. ${ }^{43}$

The court-appointed counsel, sceptical at first about the possibility of reaching an agreement, commented on the successful resolution of this case in a report published after this pilot project: "I think maybe the centre used some sort of 'magic' here." ${ }^{44} \mathrm{He}$ also presented his opinion that the manner of talking and listening enacted in the restorative justice process was considerably different from that in the legal world, which makes it difficult to expect lawyers in criminal cases to reflect on themselves and to communicate their position while at the same time maintaining the presence of mind to understand the other party's situation.

Among the cases that went through this pilot project, the case in which the harm was the most serious - the death of a victim - is evaluated as being the most successful. Because the number of cases dealt with in this pilot project is very small, it is unable to draw universal conclusions. However, in Case \#3 [Car accident], unlike other cases in this pilot project, all of the parties - the victim's family, the defendant, and his family - were so devastated by the unexpected and shocking death of the victim, and the resulting chain of suffering in their lives. Helpless in confronting this series of events, all parties lacked the capacity to unravel this complicated situation, or to control their own psychological distress. Therefore, when they recognized that the restorative justice professionals neither judged nor criticized them, but rather listened to their story and sympathized with them, they opened their minds and revealed their true feelings.

Through this case, it is already obvious that some people-even though the number is small—whose cases are currently before the criminal court would find help and succour from

\footnotetext{
42. Ibid., p. 180.

43. Ibid.

44. Ibid., p. 182.
} 
restorative justice practice. However, because only one success was observed in this pilot project, the question of which cases and which parties would be suitable for transferral from the conventional criminal justice system to restorative justice needs further investigation.

\section{DISCUSSION}

From its inception, restorative justice has attracted many objections ranging from theoretical opposition to questions of its ultimate efficacy, as well as problems with its application within or parallel to the conventional criminal justice system. ${ }^{45}$ However, the idea of restorative justice has not yet been sufficiently problematized concerning the real preference of the parties directly related to a crime for the restorative justice process itself. ${ }^{46}$ Based on the assumption that face-to-face meetings are far more humane than cold impersonal courtroom structures, restorative justice theorists proposed and developed a system of justice in which each criminal case is considered in relation to the parties directly tied to the crime and in the context of the community in which the crime occurred. They believed such a system would address the diverse needs of all individuals involved and prevent criminal action from being abstracted away from the true needs of the community.

This pilot project, which was originally designed to measure the institutional feasibility of implementing restorative justice within the Korean criminal justice system, was instead confronted with the fundamental question of restorative justice - whether people truly prefer face-toface meetings to the impersonal and structured process of criminal justice procedure. The parties in this pilot project might have previously learned concepts of crime and punishment based on individual responsibility and proportional deservedness through formal or informal legal education and relevant experience. Thus, to them, except for the parties in one case (Case \#3 [Car accident]), it was an impossible mission to understand this strange idea of restorative justice and to follow an unfamiliar way of communicating with other parties, as this process requires.

The judge in charge of this pilot project illustrated the general characteristics of victims after they were informed about the restorative justice option at trial:

In the case of most victims, they wanted damage recovery, but the only way they were familiar with was submitting petitions in criminal trials and receiving compensation through a separate civil suit. Since they had never seen or heard of any further damage recovery other than monetary compensation, it was quite difficult for them to understand that more practical and sincere damage recovery would be possible through conversation with the defendants, with help from professionals. In particular, victims who suffered severely because their damage became compounded for as long as they failed to receive any damage recovery from the defendants were hurt by or feared the idea of confronting the defendant with optimistic expectations. ${ }^{47}$

The cases in this pilot project show how rigid the parties', especially the victims', ideas of crime, retribution, and punishment are, and how challenging it can be to encourage the

45. Braithwaite (1999), pp. 79-104; Johnstone (2007), p. 598; Morris (2003), pp. 462-9; Presser \& Hamilton (2006), p. 318.

46. Lee, Angela (1996) reported the result of 16 focus group discussions carried out in New Zealand for the purpose of investigating public attitudes toward restorative justice, and indicated the possibility of obtaining a level of support for using restorative justice process in less serious offences. However, this study examined only the public's general tendency to accept reparation and victim-offender mediation, rather than asking the real preference of those directly involved in a crime.

47. Bucheon Branch Court of Incheon District Court, supra note 33, p. 24. 
parties to transition their reactions to restorative justice. In some cases, parties agreed to the referral to restorative justice, in order to avoid any disadvantage that they feared might be caused by their refusal. In others, the victims participated with doubts and distrust towards the judicial system, suspecting that the restorative justice process only serves the interests of the defendant. In yet others, the victims tried to control the whole process by using their higher structural position as a "victim" to demand excessive requests compared to other similar cases. In others, the victims revealed their overall tendency to desire the formal criminal process and its outcomes. As such, the parties in this pilot project did not act in accordance with the manner predicted by restorative justice theory.

This result is itself unsurprising, because it would be almost impossible for the parties to change their response to the crime after listening to a brief introduction of restorative justice for the first time in their lives, even though guided through it by restorative justice professionals. Despite the Bucheon Branch Court's efforts to promote social consensus on restorative justice in the local community-necessary in order to successfully run this pilot project and achieve its goals - it seemed unable to reach the actual targets of the project, namely victims and defendants of pending criminal cases. Furthermore, from the perspective of victims, the process of requesting their participation to an additional procedure of restorative justice happened abruptly, without any prior notification, in a court hearing where the victims were summoned as ex efficio sentencing witnesses. If time had been taken to distribute information about this restorative justice project to parties during the criminal justice procedure before asking their intent to participate, or if an educational session about restorative justice had been provided to parties after their decision to participate, the parties' understanding of restorative justice would likely have been enhanced and their attitudes somewhat changed.

On the other hand, even if they had been fully informed over a considerable period of time, it is still uncertain whether they would rather choose this ancient solution to crime rather than the institutionalized system of modern criminal process. In Korea, from the beginning of the 1990s, it has been seen that people depend on the judicial system heavily to resolve their everyday trivial disputes and even misuse the system as a tool to threaten other parties. ${ }^{48}$ This tendency that pervades all of society has even spurred the coining of new words like "judicialism" or "judicial omnipotence." "Furthermore, in this project, the parties' reliance on the judicial system appeared in most cases by comparing the clear offer suggested by the other party in restorative justice to the unclear outcome that could be obtained through the formal judicial process. In addition, the representative of Nonviolence Peaceforce Corea who led the restorative justice process of Case \#9 [Rob thy neighbour] complained that "the defendants kept asking the restorative justice facilitator for legal advice," $" 50$ even though he told them in advance that the facilitator is a neutral coordinator who does not give any such advice.

Illuminating this current situation in Korea, it becomes apparent that an official adoption of restorative justice in adult criminal cases in the trial-and-sentencing phase merely on the basis of its laudable humanist promises runs the real risk of producing yet another restorative

48. Kim, Jeongoh (2006), pp. 153-79; Kim, Jeong-Oh (2008), pp. 61-8; Park, Sang-ki \& Kang-woo Park (1998), pp. 125-31.

49. Park, Myeong-lim (2006).

50. Bucheon Branch Court of Incheon District Court, supra note 33, p. 81. 
justice programme in name only. The introduction of this government-oriented programme will become just one additional pathway for processing a defendant based on a judge's suggestion, or it will simply institutionalize the existing informal practice of reflecting the agreement between victim and defendant in a judge's sentencing decision. In addition, most of the parties participating in the restorative justice practices will apply the same communication methods and litigation strategies as they used in the conventional criminal procedure, including condemning, criticizing, manipulating, and retaliating against their legal adversaries, as well as maximizing their own interests. Consequently, it could end up pouring old wine into the new wineskins of restorative justice, contrary to Daniel W. Van Ness's vision of new wine in old wineskins.

In order to defend a future restorative justice programme from similar criticisms of being far from the original idea of restorative justice, it must be preceded by changes in people's reactions to and feelings about crime, the criminal justice system, and punishment. Judging from the mixed results of this pilot programme, a hasty introduction of restorative justice at trial will produce a situation where the success of restorative justice in cases will be determined by chance - each party's individual characteristics, psychological status, and realistic circumstances, their attorneys' assessment of legal matters and attitudes toward the other parties, and the restorative justice professionals' style of leading the conversation, etc. Thus, the introduction of restorative justice at trial should not be understood as merely a new kind of diversion programme, but should be viewed as an entire shift of people's values vis-à-vis their own lives, human relations, and community.

One promising aspect of this shift is that the people's direct and indirect experience in restorative justice has begun to gradually spread out in Korean society. ${ }^{51}$ This type of pilot project has been one opportunity to enhance attorneys' and the general public's awareness of restorative justice. Furthermore, the Korean public education system has approved the value of restorative justice, and peer-mediations in school violence cases have been voluntarily implemented within some middle and high schools. ${ }^{52}$ The various experiences of individuals, especially teenagers, will help prepare the future social environment to accept the idea of restorative justice at criminal trials.

\section{CONCLUSION}

The objective of this pilot project was to test the applicability of restorative justice practices to the Korean environment. The experiment illuminated the positive side of introducing restorative justice at criminal trials, but also raised many challenging issues, including the question of whether Korean citizens truly prefer a relational and communication-based process of restorative justice. Furthermore, it could be argued that only one successful case among ten indicates a low effectiveness rate of restorative justice practices. However, success or failure should not be evaluated based purely on statistics because, even if two parties in only one case sympathized with each other and restored their equilibrium, it is still worthwhile from a humanistic perspective in a hurt-, rage-, and violence-filled society. Nonetheless, aside from the evaluation of its success or failure, the challenges and questions

51. Chung, June Young, supra note 13, p. 545.

52. Gwak, Hanyoung \& Jungwoo Lee (2007), pp. 10-17; Lee et al. (2014), pp. 109-249; Lee, Ji-Hye (2014), pp. 74-82; Ryu, Byung Kwan (2013), pp. 71-9. 
raised by this pilot project should be further investigated. Rather than unquestioningly accepting the humanist promises and assumptions of restorative justice, and before rolling out its practice in Korea on a wider scale, more study is needed, otherwise it will simply end up a case of old wine in new wineskins.

\section{REFERENCES}

Bayley, David H. (2001) “Security and Justice for All," in H. Strang \& J. Braithwaite, eds., Restorative Justice and Civil Society, Cambridge: Cambridge University Press, 211-21.

Bazemore, Gordon, \& Mara Schiff (2004) "Paradigm Muddle or Paradigm Paralysis? The Wide and Narrow Roads to Restorative Justice Reform (or, a Little Confusion May Be a Good Thing)." 7 Contemporary Justice Rev 37-57.

Bazemore, Gordon, \& Mark S. Umbreit (1995) "Rethinking the Sanctioning Function in Juvenile Court: Retributive or Restorative Responses to Youth Crime." 41 Crime \& Delinquency 296-316.

Braithwaite, John (1999) "Restorative Justice: Assessing Optimistic and Pessimistic Accounts." 25 Crime \& Justice 1-127.

Braithwaite, John (2002) Restorative Justice and Responsive Regulation, New York: Oxford University Press.

Braithwaite, John, \& Heather Strang (2001) "Introduction: Restorative Justice and Civil Society," in H. Strang \& J. Braithwaite, eds., Restorative Justice and Civil Society, Cambridge: Cambridge University Press, 1-13.

Bucheon Branch Court of Incheon District Court (2014) bu-cheon-ji-won hyeong-sa-jae-pan hoe-bokjeok sa-beop si-beom-sil-si jong-hap-pyeong-ga hap-dong-po-reom: hyeong-sa-jae-pan jeol-cha-eui hoe-bok-jeok sa-beop do-ib-e gwan-han non-ui [A Forum for a Comprehensive Review of the Restorative Justice Pilot Project in Bucheon Branch Court: Discussion for Introducing Restorative Justice in Criminal Trials], Bucheon: Bucheon Branch Court of Incheon District Court.

Chun, Jung Hwan (2015) "Approach to Improve Reconciliation Recommendation System under the Juvenile Act." 39 The Correction Welfare Society of Korea 1-31.

Chung, June Young (2013) "Healing, Responsibility, and Reintegration: Till We Have the Restorative Justice." 134-3 The Justice 522-49.

Clear, Todd R. (2004) "Thoughts about Action and Ideology in Criminal Justice Reform." 7 Contemporary Justice Rev 69-73.

Dzur, Albert W., \& Susan M. Olson (2004) "The Value of Community Participation in Restorative Justice.” 35 Journal of Social Philosophy 91-107.

Gang, Ho-Seong, \& Seung-Weon Lee (2011) "A Study on the Restorative Justice and Probation Services in Korea." 5 Asian Forum for Corrections 267-99.

Gwak, Hanyoung, \& Jungwoo Lee (2007) "Conflict Resolution Education in Social Studies: Focused on Peer Mediation." 39 Theory and Research in Citizenship Education 1-21.

Harris, M. Kay (2004) "An Expansive, Transformative View of Restorative Justice.” 7 Contemporary Justice Rev 117-41.

Johnstone, Gerry (2004) "How, and in What Terms, Should Restorative Justice Be Conceived?," in H. Zehr \& B. Toews, eds., Critical Issues in Restorative Justice, Monsey: Criminal Justice Press, 5-15.

Johnstone, Gerry (2007) "Critical Perspectives on Restorative Justice," in G. Johnstone \& D. W. Van Ness, eds., Handbook of Restorative Justice, Cullompton: Willan Publishing, 598-614.

Johnstone, Gerry, \& Daniel W. Van Ness (2007) “The Meaning of Restorative Justice," in G. Johnstone \& D. W. Van Ness, eds., Handbook of Restorative Justice, Cullompton: Willan Publishing, $5-23$.

Joo, Jae-Ung (2014) "An Analysis of the Current Situation of Criminal Mediation System and Effectiveness." 2 beom-nyul-sil-mu-yeon-gu 211-75.

Jung, Hee-Cheol (2011) "A Practical Plan of Reconciliation Recommendation System and Its Problems under the Juvenile Act." 17 Korean Juvenile Protection Rev 91-113.

Jung, Ji-Young (2013) "Criminal Case Mediation in Korea." 5 The Korea Criminal Procedure Law 68-82. 
Kang, Jee-Myoung (2012) "A Study on the Reconcilitation [sic] Recommendation System under the Juvenile Act." 24 Korean Journal of Criminology 99-130.

Karp, David R. (2004) "Birds of a Feather: A Response to the McCold Critique of Community Justice." 7 Contemporary Justice Rev 59-67.

Kim, Eun-Kyeong (2009) "A Study on Restorative Justice Practices Responding against Young Offences." 13 Korean Juvenile Protection Rev 51-95.

Kim, Eun-Kyung (2008) "Results of Research from Restorative Justice Experiments against School Violence in Korea, 2007." 19 Korean Criminological Review 93-145.

Kim, Hang-Gon (2009) "A Study on Seeking the Juvenile Justice Development Direction through a Trial Operation of Restorative Justice in the Police Stage." 14 Ewha Law Journal 29-51.

Kim, Hyun (2009) "Restoration, Participation and Prevention in Criminal Justice: Around the Prosecutory [sic] Affairs." 14 Ewha Law Journal 53-68.

Kim, Jeong-Oh (2008) "The Archetype and Transformation of Korean Legal Culture." 3 Korea LawRelated Education Association 49-72.

Kim, Jeongoh (2006) Korean Legal Culture: Understanding, Structure and Change, Paju: Nanam Publishing House.

Kim, Yong-Uk (2008) "Criminal Mediation in Korea: Restorative Justice Programme?" 19 Korean Criminological Rev 205-29.

Kim, Yongshik (2013) "Case Study of Restorative Justice at Correctional Stage in Korea." 6 Asian Forum for Corrections 273-95.

Korea Legislation Research Institute, Statutes of the Republic of Korea (2017a) "Crime Victim Protection Act," http://elaw.klri.re.kr/kor_service/lawView.do?hseq=33076\&lang=ENG (accessed 29 March 2017).

Korea Legislation Research Institute, Statutes of the Republic of Korea (2017b) "Juvenile Act," http:// elaw.klri.re.kr/kor_service/lawView.do?hseq=37128\&lang=ENG (accessed 29 March 2017).

Korea Legislation Research Institute, Statutes of the Republic of Korea (2017c) "Regulation on Criminal Procedure," http://elaw.klri.re.kr/kor_service/lawView.do?hseq=26696\&lang=ENG (accessed 6 November 2017).

Kurki, Leena (2000) "Restorative and Community Justice in the United States." 27 Crime \& Justice 235-303.

Lee, Angela (1996) "Public Attitudes towards Restorative Justice," in B. Galaway \& J. Hudson, eds., Restorative Justice: International Perspectives, Monsey: Criminal Justice Press, 337-347.

Lee, Bo-Young (2015) "Criminal Mediation as a Practice of Restorative Justice." 26 Han Yang Law Rev 57-81.

Lee, Dong Weon (2011) "Participants' Assessments on the Process of Criminal Mediation: Focusing on the Survey on the Offenders and Victims." 13 Korean Association of Police Science 111-36.

Lee, Dong Weon, \& Hyun Seok Yoon (2016) "Empirical Evaluation and Analysis of Implementation and Outcomes of Criminal Mediation: Based on Criminal Mediation Cases in 2010 and 2014." 18 Korean Association of Police Science 179-205.

Lee, Eugene, Chang-Hun Lee, \& Jee-Myoung Kang (2014) Study on the Introduction of a Restorative Justice Model as a Means to Resolve of School Violence, Sejong: National Youth Policy Institute.

Lee, Ho-Joong (2009) "Restorative Justice Discourse and Practice." 14 Ewha Law Journal 1-27.

Lee, Ji-Hye (2014) "A Study on Conflict Resolution through Peer Mediation." 9 Korea Law-Related Education Association 65-90.

Lee, Jin-Kuk (2008) "hoe-bok-jeok sa-beob-ui gwan-jeom-e-seo bon hyeong-sa-jo-jeong-sil-mu-ui mun-je-jeom" ["Problems of Criminal Mediation Practices from the Perspective of Restorative Justice"]." 19 Korean Criminological Rev 5-31.

Lee, Jin-Kuk (2009) "gae-jeong so-nyeon-beop-sang hoe-bok-jeok sa-beop-je-do-e gwan-han bi-panjeok geom-to" ["Critical Review of the Restorative Justice System in the Revised Juvenile Act"]." 17 Korean Association of Victimology 355-75.

Lee, Sung Chil (2009) "The Application Condition and Prospective of Restorative Justice in the Korea's Probation [sic]." 14 Ewha Law Journal 111-37. 
Lee, Young Hoon (2009) "Restorative Justice at Trial: Present and Future Perspectives." 14 Ewha Law Journal 69-86.

Lee, Young-Ho (2009) "Practical Plan of Restorative Justice at the Juvenile Protection Institution." 14 Ewha Law Journal 87-110.

Marshall, Tony F. (2003) "Restorative Justice: An Overview," in G. Johnstone, ed., A Restorative Justice Reader: Texts, Sources, Context, Cullompton: Willan Publishing, 28-45.

Morris, Allison (2003) "Critiquing the Critics: A Brief Response to Critics of Restorative Justice," in G. Johnstone, ed., A Restorative Justice Reader: Texts, Sources, Context, Cullompton: Willan Publishing, 461-76.

Park, Jung-Sung, \& Hyo-Jin Kim (2012) "The Correction and Restorative Justice in the Private Prisons." 9 Korean Association for Public Security Administration 87-109.

Park, Kwang-Hyun (2014) "A Study on the Criminal Mediation of Restorative Justice." 20 Law and Policy Rev 259-85.

Park, Myeong-lim (2006) "sabeop, sosong manneung sahoe-ro gal geon-ga" ["Will We Move towards a Society with Judicial Omnipotence?'], JoongAng Ilbo, 15 January, http://news.joins.com/article/ 2108510 (accessed 18 August 2017).

Park, Sang-ki, \& Kang-woo Park (1998) A Study on the Complaint System in Korea, Seoul: Korean Institute of Criminology.

Park, Sang-Sik (2007) "A Possibility of Practice of Restorative Justice on the Stage of Correction." 10 The Correction Welfare Society of Korea 109-31.

Presser, Lois, \& Cynthia A. Hamilton (2006) "The Micropolitics of Victim-Offender Mediation." 76 Sociological Inquiry 316-42.

Ryu, Byung Kwan (2013) "A Study on the 'Peer Mediation Programs' for the Prevention of School Violence: Focused on the Peer Mediation Programs in U.S. Schools." 23 Korean Juvenile Protection Rev 61-84.

Shearing, Clifford (2001) "Transforming Security: A South African Experiment," in H. Strang \& J. Braithwaite, eds., Restorative Justice and Civil Society, Cambridge: Cambridge University Press, 14-34. Sherman, Lawrence W. (2001) "Two Protestant Ethics and the Spirit of Restoration," in H. Strang \& J. Braithwaite, eds., Restorative Justice and Civil Society, Cambridge: Cambridge University Press, 35-55.

Shin, Han Mi (2011) "New Attempts in the Korean Juvenile Protection Justice: Current Status and Challenges of the 'Youth Court in the Trial' and the 'Advisory System for Conciliation'." 14 Asian Women Law 69-102.

Shin, Yang-Kyun (2009) "A Introductory Study on Criminal Mediation System in Korea." 44 Dong-A Law Review 445-71.

Shin, Yong-Hae (2009) "The Actual Condition of the Application of Restorative Justice in Correction and its Development Direction." 14 Ewha Law Journal 139-53.

Sohn, Yoi Chull (2011) "The Application of Restorative Justice in Community Service and Attendance Center Order." 16 Ewha Law Journal 87-109.

Song, Gil Yong (2007) "Legal Practice Study: New Concept on Criminal Mediation." 56 Lawyers Association Journal 136-86.

Strang, Heather (2001) "The Crime Victim Movement as a Force in Civil Society," in H. Strang \& J. Braithwaite, eds., Restorative Justice and Civil Society, Cambridge: Cambridge University Press, 69-82.

Sun, Ui Jong (2010) "A Practical Plan of Compromise Recommendation System under the Juvenile Act." 15 Ewha Law Journal 35-49.

Umbreit, Mark S. (2001) The Handbook of Victim Offender Mediation: An Essential Guide to Practice and Research, San Francisco: Jossey-Bass.

Umbreit, Mark S., Robert B. Coates, \& Betty Vos (2004) "Restorative Justice versus Community Justice: Clarifying a Muddle or Generating Confusion?" 7 Contemporary Justice Rev 81-89.

Van Ness, Daniel W. (1993) "New Wine in Old Wineskins: Four Challenges of Restorative Justice." 4 Criminal Law Forum 251-76.

Wachtel, Ted, \& Paul McCold (2001) “Restorative Justice in Everyday Life," in H. Strang \& J. Braithwaite, eds., Restorative Justice and Civil Society, Cambridge: Cambridge University Press, 114-29. 